\title{
The Potential of Underutilized Vegetables of Assam as a Source of Nutrition - A Review
}

\author{
Sanchayeeta Gohain $^{1 *}$, M. Neog ${ }^{2}$ and Sanjoy Borthakur ${ }^{1}$ \\ ${ }^{1}$ Subject Matter Specialist (Horticulture), KVK, Tinsukia, India \\ ${ }^{2}$ Assam Agricultural University, Jorhat, India
}

*Corresponding author

\begin{abstract}
A B S T R A C T
\section{Keywords}

Underutilized vegetables,

Essential vitamins,

Proteins,

Micronutrients,

Livelihood

improvement

Article Info

Accepted:

20 September 2020

Available Online:

10 October 2020

The underutilized indigenous vegetables are rich source of, protein, essential vitamins, micronutrients and other phytonutrients etc. and many of these vegetables have a better nutritional value compared to other known vegetables like tomato or cabbage. But the potential of these vegetables are not explored commercially. Various underutilized vegetables like Water spinach, Common Purslane, Indian spinach, tree bean, winged bean etc. are embedded with vitamins, amino acids, minerals, protein, dietary fibre etc. have high antioxidant activities and hence can effectively address the issues related to mal nutrition and nutritional security. Apart from creating stability to the eco system these underutilized vegetables can be a help in increasing the economy of the rural poor.
\end{abstract}

\section{Introduction}

With the annual population growth rate of $1.8 \%$, the demand for food, feed and bio fuel in the world is growing day by day. It is projected that to cater the food demand of whole world, the production of agriculture has to increase by $70 \%$ by the year 2050 . Till date, there are estimated 75000 species of edible plants of which interestingly only $30 \%$ are being utilized to provide $90 \%$ of the world's food. Therefore, there is a huge potential to explore the underutilized crops as food source. In the year 2017-18 from an area of 10249 hector, India produces 18, 7474 MT of vegetables and this amazing achievement was contributed by only few major vegetables like brinjal, cauliflower, cabbage, peas, onion etc. Though the underutilized vegetables are always been a part of peoples everyday diet, but underutilized vegetables has not been given much consideration to explore commercially. India has the advantage of having a varied agro climatic situation which allows to grow more than 60 cultivated and about 30 lesser known vegetable crops. Even 
though the underutilized vegetables has the tremendous potential to contribute to livelihood improvement, nutritional security and environment sustainability, the research and cultivation of these crops on commercial basis is still very narrow.

\section{Importance of underutilized vegetables}

The indigenous underutilized vegetables are not only packed with protein, essential vitamins, micronutrients, and other phytonutrients etc but many of these vegetables have a better nutritional value compared to other known vegetables like tomato or cabbage (Keatinge et al., 2011). Many social world issues like poverty, malnutrition, and economic upliftmen can be address efficiently by giving proper emphasis on underutilized vegetables. As the traditional crops typically do not meet modern standards for uniformity and other characteristics they have been neglected by breeders from the private and public sectors. But the traditional varieties have an immense potential to contribute to the world food production for their biotic resistance, tolerance to abiotic stress, yield and quality. Underutilized vegetables are rich source of nutrients including vitamins, minerals and other health promoting elements including high antioxidant activity which help in the diversification of diet leading to more balanced source of micronutrients. Apart from creating stability to the eco system these underutilized vegetables can be a help in creasing the economy of the rural poor.

\section{Nutritional potential of some underutilized vegetables}

\section{Ipomoea aquatica (Water spinach)}

Water spinach is a herbaceous aquatic or semi-aquatic trailing type perennial plant belonging to the family Convolvulaceae whose tender twigs with leaves are used as vegetable in many parts of India including North east India, Kerala and Tamilnadu. The plant is generally grown wild and rich in minerals. The leaves consist of high moisture $(72.83 \pm 0.29 \%)$, ash $(10.83 \pm 0.80 \%)$, crude lipid (11.00 $\pm 0.50 \%)$, crude fibre (17.67 \pm $0.35 \%)$ and available carbohydrate (54.20 \pm $0.68 \%)$. The leaves have a remarkable amount of magnesium (301.64 $\pm 12.69 \mathrm{mg} / 100 \mathrm{~g})$ potassium $(5,458.33 \pm 954.70 \%)$, calcium $(416.70 \pm 5.77 \mathrm{mg} / 100 \mathrm{~g})$ and phosphorus (109.29 $\pm 0.55 \mathrm{mg} / 100 \mathrm{~g}$ ), (Umar et al., 2006). Iron deficiency, according to World Health Organisation (WHO); affect about 3.7 billion people out of which 2 billion people are anaemic (Meng et al., 2005) and Ipomoea aquatica can be use as a reliable source against iron deficiency as it contain a significant amount of iron $(210.30 \pm 2.47$ $\mathrm{mg} / 100 \mathrm{~g}$ ).

\section{Dendrocalamus strictus (Bamboo shoot)}

Bamboo shoot is a traditional food for many people around the world and every year two million tonnes of edible bamboo shoots are consumed in the world (Yang et al., 2008). Generally the young shoots are cooked for vegetables. Bamboo shoots contain high proteins, amino acids, carbohydrates, many important minerals, and vitamins and thus have a immense potential of being used as important health food, The shoots have a good profile of minerals, consisting mainly of potassium $(\mathrm{K})$, calcium $(\mathrm{Ca})$, manganese, zinc, chromium, copper, iron $(\mathrm{Fe})$, plus lower amounts of phosphorus (P), and selenium (Shi and Yang 1992; Nirmala et al., 2007). Fresh shoots are a good source of thiamine, niacin, vitamin A, vitamin B6, and vitamin $\mathrm{E}$ (Visuphaka, 1985; Xia, 1989). They are rich in protein, containing between 1.49 and 4.04 (average $2.65 \mathrm{~g}$ ) per $100 \mathrm{~g}$ of fresh bamboo shoots. Bamboo shoots contain 17 amino acids, 8 of which are essential for the human 
body (Qiu, 1992; Ferreira et al., 1995). Amino acid content in bamboo shoot is found to be much higher than in other vegetables such as cabbage, carrot, onion and pumpkin (Nirmala et al., 2001). In bamboo shoots Tyrosine amounts to $57 \%$ to $67 \%$ of the total amino acid content (Kozukue et al., 1999), which is required to facilitate biochemical metabolism of our body. As the fat content is comparatively low $(0.26 \%$ to $0.94 \%)$ so it can be a healthy food for people with diabetes and heart disease.

\section{Portulaca oleracea (Common Purslane)}

This traditionally grown vegetable can be termed as power food because of its high nutritive and antioxidant properties. It has a better nutritional quality than the major cultivated vegetables, with higher betacarotene, ascorbic acid, and alpha-linolenic acid (Lui 200 et al.,) . Purslane contains the highest content of vitamin A among green leafy vegetables. It also contains vitamin C and B-complex vitamins like riboflavin, niacin, and pyridoxine. It provides highest dietary minerals such as potassium $(494 \mathrm{mg} / 100 \mathrm{~g})$ followed by magnesium (68 mg/100 g), calcium (65 mg/100 g), phosphorus $(44 \mathrm{mg} / 100 \mathrm{~g})$, and iron (1.99 mg/100 g).

Basela rubra (Indian spinach): Commonly known as Indian or Malabar spinach, this herbaceous annual or biennial climbing herb is found in tropical and sub-tropical areas It belongs to family Basellacae, is a branched, succulent,, twining herbaceous vine and several meters in length. The easy adaptation to a variety of soils and climates, Basella sp is considered one of the best tropical spinach. This wild leafy vegetables, is significantly rich in various nutrition and per 100 grams (g) edible portion of Indian spinach leaves contain 23.0(kcal) of Energy; 2.0 gm protein; $0.3 \mathrm{gm}$ of fat; $3.0 \mathrm{gm}$ of Carbohydrates; 0.9 gm of Fiber and $2.2 \mathrm{gm}$ of ash. It also contains calcium 2.32, potassium 5.8, magnesium 0.06, sodium 5.11, iron $0.04 \mathrm{mg} / 100 \mathrm{gm}$. (Nirmala et al., 2011). Indian spinach is also rich in Vitamin A (456.0mg); Thiamine $(0.04 \mathrm{mg})$; Riboflavin $(0.12 \mathrm{mg})$; Niacin (0.5mg) and Ascorbic acid (89.027 $\mathrm{mg}$ ). Moreover, it was found that daily consumption of Malabar spinach affects storage of vitamin A positively (Haskell et al 2004) (Table 1).

\section{Psophocarpus tetragonolobus (Winged bean)}

The winged bean is an underutilised species but has the potential to become a major multiuse food crop. The entire winged bean plant is edible. The leaves, flowers, roots, and bean pods can be eaten raw or cooked; the pods are edible even when raw and unripe. The seeds are edible after cooking. Each of these parts are very nutritious and contains vitamin A, vitamin C, calcium, and iron. The tender pods, which are the most widely eaten part of the plant, are best when eaten before they exceed 2.5 centimetres (1.0 in) in length. The young leaves can be picked and prepared as a leaf vegetable, similar to spinach. The nutrient rich, tuberous roots have a nutty flavour. They are about $20 \%$ protein; winged bean roots have more protein than many other root vegetables. The leaves and flowers are also high in protein $(10-15 \%)$. The seeds are about $35 \%$ protein and $18 \%$ fat. Winged beans consist of high amount of niacin which helps in reducing the formation of blood clots by reducing platelet aggregation which reduce the risks of cardiovascular disease.

\section{Parkia roxburghii (Tree Bean)}

Tree bean is a much-branched legume of medium height $(10-12 \mathrm{~m})$ with bipinnate leave and is very popular in North East India where the long tender pods are used as 
vegetables. The total essential amino acids amounted to $33 \%, 36 \%$ and $39 \%$ in the tender, immature, mature pods, respectively, and $42 \%$ in the kernels (Table 2).

Table.1 Purslane (Portulaca oleracea) (Nutritive value per 100 g) Source: USDA National Nutrient data

\begin{tabular}{|l|l|}
\hline Component & Nutrient value \\
\hline Energy & $16 \mathrm{Kcal}$ \\
\hline Carbohydrate & $3.4 \mathrm{~g}$ \\
\hline Protein & $01.30 \mathrm{~g}$ \\
\hline Total Fat & $0.1 \mathrm{~g}$ \\
\hline Folates & $12 \mu \mathrm{g}$ \\
\hline Niacin & $0.480 \mathrm{mg}$ \\
\hline Riboflavin & $0.112 \mathrm{mg}$ \\
\hline Vitamin A & $1320 \mathrm{IU}$ \\
\hline Vitamin C & $21 \mathrm{mg}$ \\
\hline Sodium & $45 \mathrm{mg}$ \\
\hline Potassium & $494 \mathrm{mg}$ \\
\hline
\end{tabular}

Table.2 Nutrient content of Parkia roxburghii (Longvah and Deosthale, 1998)

\begin{tabular}{|c|c|c|c|c|}
\hline Nutrition & Tender pod & $\begin{array}{l}\text { Immature } \\
\text { pod }\end{array}$ & Mature pod & $\begin{array}{l}\text { Mature } \\
\text { kernel }\end{array}$ \\
\hline $\operatorname{Protein}(\%)$ & 12.1 & 15.6 & 18.8 & 28.8 \\
\hline Fat $(\%)$ & 1.0 & 7.8 & 15.5 & 33.5 \\
\hline $\operatorname{Ash}(\%)$ & 7.4 & 6.9 & 6.1 & 5.7 \\
\hline Carbohydrate \& fibre (\%) & 71.1 & 62.6 & 52.9 & 22.0 \\
\hline Energy(Kcal) & 342 & 383 & 426 & 505 \\
\hline Phosphorous(mg $\left.100 \mathrm{~g}^{-1}\right)$ & 320 & 315 & 298 & 270 \\
\hline Magnesium (mg $100 \mathrm{~g}^{-1}$ ) & 520 & 505 & 480 & 420 \\
\hline Calcium(mg $\left.100 \mathrm{~g}^{-1}\right)$ & 176 & 181 & 172 & 180 \\
\hline $\operatorname{Iron}\left(\mathrm{mg} 100 \mathrm{~g}^{-1}\right)$ & 8.8 & 8.4 & 9.1 & 13.3 \\
\hline Manganese (mg $\left.100 \mathrm{~g}^{-1}\right)$ & 2.8 & 2.1 & 2.4 & 2.9 \\
\hline Zinc $\left(\mathrm{mg} 100 \mathrm{~g}^{-1}\right)$ & 3.1 & 3.4 & 3.3 & 5.6 \\
\hline Copper $\left(\mathrm{mg} 100 \mathrm{~g}^{-1}\right)$ & 0.6 & 0.5 & 0.6 & 0.7 \\
\hline
\end{tabular}

\section{Colocasia esculanta}

This ancient crop belongs to family Araceae and is grown throughout the humid tropics for its edible corns, cormels and leaves, as well as for other traditional uses. Fresh colocasia leaves (green variety) contain moisture 82.7 $\mathrm{g}$, protein $3.9 \mathrm{~g}$, fat $1.5 \mathrm{~g}$, minerals $2.5 \mathrm{~g}$, crude fiber $2.9 \mathrm{~g}$, carbohydrate $6.8 \mathrm{~g}$, energy
$56 \mathrm{Kcal}$, calcium $227 \mathrm{mg}$, phosphorus $82 \mathrm{mg}$, iron $10 \mathrm{mg}$, copper $0.18 \mathrm{mg}$ (Gopalan et al., 1989). The high level of dietary fibre found in the leaf of colacasia is also beneficial as it takes an active role in the regulation of intestinal transit by increasing the dietary bulk (Saldanha, 1995). The corm of colocasia contains $11 \%$ crude protein and $87 \%$ carbohydrate content on DM basis. These 
reported carbohydrate and protein values are even higher than other root crops like yam, cassava or sweet potato (FAO, 1999)

In conclusion though the prospective of the underutilized vegetables to utilize as foods is enormous, it has not been explored properly. The main probable causes behind this due to lack of planting materials, absence of information on nutritional as well as medicinal importance and lack of information on production technique of these crops. The soil and climate of Assam are favourable for the cultivation of diverse minor vegetables but the information on package of practices of the minor vegetables are very limited. The underutilized vegetable can also be vital in employment generation and also has the capability to handle adverse climatic conditions. These advantages may boost these underutilized vegetables profitable to growers, consumers and environmentalists also. But if the food and nutritional security has to safeguard, there is an immediate \& urgent need is to take up programmes on genetic resources exploration, management, and utilization \& improvement of underutilized vegetable crops. These underutilized vegetables imbedded with all the nutritional benefit can play an significant role in shortening the gap of per capita consumption availability of poor which help in tackling the nutrition deficiency problem to a great extend.

\section{References}

Aung, L.H., Harris, C.M. and Jenner ,J.F. (2004). Chemical growth regulators on postharvest sprout development of Sechium edule Swartz. International Journal of Expert Botany 53: 155164.

Anwar, F. and Bhanger, M.I. (2003). Analytical characterization of Moringa oleifera seed oil grown in temperate regions of Pakistan. Journal of Agricultural Food Chemistry . 51: 6558- 6563.

Chumark, P., Khunawat, P., Sanvarinda, Y., Phornchirasilp, S., Phumala, N., Morales. L., Phivthongngam, P., Ratanachamnong, S., Srisawat, S. \& Pongrapeeporn, K.S. (2008). The in vitro and ex vivo antioxidant properties, hypolipidaemic and antiatherosclerotic activities of water extract of Moringa oleifera Lam. leaves. Journal of Ethnopharmacology. 116: 439-446.

Fahey, J.W. (2005). Moringa oleifera: A Review of the Medical Evidence for Its Nutritional, Therapeutic, and Prophylactic Properties. Part 1. Trees for Life Journal 1: 5

Ferreira, V.L.P., Azzini, A., de Figueriredo, I.B., Salgado, A.L.B., Barbieri, M.K. (1995). Evaluation of bamboo shoots for human consumption. Coletanea do Instituto de Tecnologia de Alimento, Brazil. 16: $23-36$.

FAO. Taro Cultivation in Asia and the Pacific, Food and Agriculture Organization of the United Nations (FAO), Rome, Italy, 1999.

Gopalan, C., Rama Sastri, B. V. R. and Balsubramaniam, S. C. (1989). Nutritive value of Indian foods, National Institute of Nutrition (ICMR) Hyderabad, pp, 49.

Goyal, B.R., Agrawal, B.B., Goyal , R K and Mehta, A.A. (2007). Phytopharmacology of Moringa oleifera Lam. An overview. Natural Product Radiance. 4: 347-353.

Haskell ,M.J., Jamil, K.M., Hassan, F., Preerson ,J.M. and Hassian, M.I., (2004). Daily consumption of Indian Spinach (Basella alba) or sweet potatoes has positive effect on total body vitamin A store in Bangladeshi 
men. The American Journal Clinical Nutrition . 80: 705-714.

Keatinge, J.D.H., Yang, R.Y., Hughes, J.D.A., Easdown, W.J. and Holmer, R. (2011). The importance of vegetables in ensuring both food and nutritional security in attainment of the Millennium Development Goals. Food Sci. 3:491- 501.

Kozukue, E., Kozukue, N. and Tsichida, H. (1999). Changes in several enzyme activities accompanying the pulp browning of bamboo shoots during storage. Journal of Japanese Society of Horticultural Science. 68 (3): 689-693.

Liu, L., Howe, P., Zhou, Y-F., Xu Z-Q, Hocart ,C., Zhang ,R. (2000). Fatty acids and $\beta$-carotene in Australian purslane (Portulaca oleracea) varieties. Journal of Chromatography .893(1):207-213

Longvah ,T. and Deosthale ,Y. G .( 1998). Nutrient composition and food potential of Parkia roxburghii, a less known tree legume from northeast India. Food Chemistry.62(4) :477-481

Meng, F., Wei, Y. and Yang, X. (2005). Iron content and bioavailability in rice. Journal of Trace Elements of Medicine and Biology . 18: 333-338.

Nirmala, C., Madhoo, S.B. and Sheena, H.( 2001). Nutritional Properties of Bamboo Shoots: Potential and Prospects for Utilization as a Health Food. Comprehensive Reviews in Food Science and Food Safety. 10:153-169.

Nirmala, C., Saroja, S. and Gayathri G. (2011).Antidiabetic Activity of Basella rubra and its Relationship with the Antioxidant Property A. British Biotechnology Journal .1(1): 1-9

Nirmala, C., David, E. and Sharma, M.L. (2007). Changes in nutrient components during ageing of emerging juvenile bamboo shoots. International Journal Food Science Nutrition. . 58: 345-352.

Ordonez, A.A, Gomez, J.D. and Isla, M.A. (2006). Antioxidant activities of Sechium edule (Jacq.) Swartz extracts. Food Chemistry. 97: 452-458.

Peixoto, J.R., Silva, G.C., Costa, R.A. de Sousa Fontenelle, J.R., Vieira, G.H. Filho A.A. and dos Fernandes Vieira, R.H. (2011). In vitro antibacterial effect of aqueous and ethanolic Moringa leaf extracts. Asian Pacific Journal or Tropical Medicine. 4: 201204.

Qiu, F.G. (1992). The recent development of bamboo foods. Proceedings of the International Symposium on Industrial Use of Bamboo. International Timber Organization and Chinese Academy of Forestry, Beijing, China: Bamboo and its Use. 333-337.

Saldanha, L.G.( 1995). Fibre in the diet of U. S. Children: results of national surveys. Something missed,

Shi, Q.T. and Yang, K.S. (1992). Study on relationship between nutrients in bamboo shoots and human health. Proceedings of the International Symposium on Industrial Use of Bamboo. International Tropical Timber Organization and Chinese Academy, Beijing, China: Bamboo and its Use. 338- 346.

Shukla, S., Bhargava, A., Chatterjee, A., Srivastava, A. and Singh, S.P.(2006). Genotypic variability in vegetable amaranth (Amaranthus tricolor L for foliage yield and its contributing traits over successive cuttings and years. Euphytica.151(1):103-110.

Verma ,V.K., Jha, A.K. and Singh, B.K. (2014). Nutritional properties of different fruit parts of popular chowchow genotype grown in $\mathrm{NEH}$ 
Region of India. Vegetable Newsletter $.1(1): 8$.

Saade, R.L. (1996). Chayote. Sechium edule (Jacq.) Sw.: Promoting the conservation and use of underutilized and neglected crops. International Plant Genetic Resources Institute, Rome, Italy

Visuphaka, K.( 1985). The role of bamboo as a potential food source in Thailand. Proceedings of the International Bamboo Workshop;
1985 Oct 6-14; Hangzhou, China: Recent Research on Bamboos.301303.

Umar, K. J., Hassan, L.G., Dangoggo, S. M. and Ladan, M. J. (2007). Journal of applied Science. 7(6): 803-809

Xia, N.H. (1989). Analysis of nutritive constituents of bamboo shoots in Guangdong. Acta Botanica Austro Sinica. 4: 199- 206.

\section{How to cite this article:}

Sanchayeeta Gohain, M. Neog and Sanjoy Borthakur. 2020. The Potential of Underutilized Vegetables of Assam as a Source of Nutrition -A Review. Int.J.Curr.Microbiol.App.Sci. 9(10): 2873-2879. doi: https://doi.org/10.20546/ijcmas.2020.910.346 